\title{
15
}

\section{How Well Do European Child-Related Leave Policies Support the Caring Role of Fathers?}

\author{
Alzbeta Bartova and Renske Keizer
}

During the last 50 years, fathers have become more and more involved in parenting (Hook, 2006; Maume, 2010; Yeung, Sandberg, Davis-Kean, \& Hofferth, 2001). Although scholars have shown that breadwinning remains a strong component of the cultural conceptions of men's parenting (e.g., Christiansen \& Palkovitz, 2001; LaRossa, 1997), this role is increasingly being complemented with a diversity of social roles, such as caregiver and nurturing parent. Despite the prevalent "new father" discourse, however, parenting remains gendered. Fathers continue to spend less time taking care of their children than mothers, even when both parents work full time (Dermott \& Miller, 2015; Doucet, 2013; Kan, Sullivan, \& Gershuny, 2011), and they do less "solo" parenting than mothers (Raley, Bianchi, \& Wang, 2012; Yeung et al., 2001).

However, the fact that fathers spent relatively little time with their children does not stem from reluctance or unwillingness (see Grunow \& Evertsson, 2016, 2019). Most fathers indicate that they want to be more involved in the lives of their children. Data from the International Men and Gender Equality Survey (IMAGES) show that most fathers report that they would work less if it meant that they could spend more time with their children. However, various factors, such as lack of institutional support for paternal

\footnotetext{
A. Bartova $(\varangle) \cdot$ R. Keizer

Erasmus University Rotterdam, Rotterdam, The Netherlands

e-mail: alzbeta.bartova@kuleuven.be

R. Keizer

e-mail: keizer@essb.eur.nl 
childcare, financial constraints, or worries about employer discrimination, often refrain men from actually spending more time with their children (Grunow \& Evertsson, 2016, 2019; Wilson \& Prior, 2010). Enabling men to become more active in their children's lives facilitates men to be as involved as they want to be, and, even more important, brings benefits to the lives of their children, their partners, and their own lives, and the world around them (Levtov, Van der Gaag, Greene, Kaufman, \& Barker, 2015).

In this chapter, we analyze how contemporary family policies in Europe support caregiving role of fathers. We focus our analysis solely on maternity, paternity, parental, and childcare leaves, as these are the policies that have the strongest potential to facilitate fathers' participation in childcare. With an exception of paternity leave, the leave policies were introduced in many countries to primarily protect health of mothers and babies, and to facilitate women's labor market participation (Sigle-Rushton, Goisis, \& Keizer, 2012). The caring responsibilities of fathers have not been legally recognized for a long time. Only in the 1970s the first European countries started to recognize fathers' rights to care. Despite that, women remain to be the primary carers in virtually all European countries, and fathers' use of leave entitlements considerably vary across countries. We are interested in the extent to which European countries recognize the caring responsibilities of fathers toward their children and partners, and the value they place on fathers' caring role. To do so, we analyze the designs of individual leave policies and compare them with the available data on their uptake by fathers in 13 European countries that represent different geographical regions to capture the variation in the state approach to caregiving fathers.

\section{Why Do We Need Caring Fathers?}

Growing empirical evidence demonstrates that fathers' involvement in childcare has an immense value not only for their children and partners but also for the whole society. Active involvement of fathers in childcare has been found to be important for men's own physical and psychological health, relationship stability, child development, women's labor force participation, and their psychological well-being, but also on the intergenerational transmission of fathers' involvement, which has a potential to strengthen the abovementioned positive impressions in future generations. Below we provide a very short overview. It is important for readers to realize that most of the findings we refer to below are based on research on heterosexual couples. This focus comes with certain limitations. For example, when investigating 
the impact of father involvement on child outcomes in heterosexual couples, it is very difficult to disentangle whether the effects found are related to the biological sex of the parent or their gender (and gendered division of tasks). As such, more research on same-sex couples, in this example, gay fathers, is needed - see Chapter 16 by Evertsson, Jaspers, and Moberg in this volume for new insights on family formation and leave rights in same-sex parent families.

Studies have stressed the importance of getting men involved in their (unborn) child's life as early as possible. When men are engaged from the start of children's lives, for example, by participating in prenatal care, they are much more likely to remain actively involved in childcare when the child is older (Cabrera, Fagan, \& Farrie, 2008). Moreover, men's involvement during pregnancy and in the days and weeks after giving birth benefits women's physical recovery after birth and is shown to contribute to lower rates of post-partum depression (Plantin, Olukoya, \& Ny, 2011). Several studies report that being an involved father is good for men themselves as well (Keizer, Dykstra, \& Poortman, 2009; Knoester \& Eggebeen, 2006). Men who are actively involved in the daily lives of their children live longer, have fewer mental or physical health problems, are less likely to abuse drugs, are more productive at work, and report being happier than fathers who are less involved with their children (Keizer, Dykstra, \& Van Lenthe, 2011; Knoester \& Eggebeen, 2006). Higher involvement of fathers in childcare activities has also been associated with women's higher satisfaction with the couple relationship (Carlson, Hanson, \& Fitzroy, 2016; Risman \& Johnson-Sumerford, 1998) and is linked with lower likelihoods of getting divorced (Kotsadam \& Finseraas, 2011).

Although there is an ongoing scholarly debate about the roles of fathers and mothers in parenting (Cabrera, Fitzgerald, Bradley, \& Roggman, 2014; Fagan, Day, Lamb, \& Cabrera, 2014; Grossmann et al., 2002; Lamb, 2010; Paquette, 2004), there is more and more evidence suggesting that fathers' involvement influences children's development in similar ways as the mothers'. There is a general consensus in the literature that fathers' involvement in childcare is positively related to children's behavioral and emotional development (for reviews see Cabrera, Tamis-LeMonda, Bradley, Hofferth, \& Lamb, 2000; Lamb \& Lewis, 2013; Sarkadi, Kristiansson, Oberklaid, \& Bremberg, 2008). Furthermore, fathers' involvement has also been linked to higher cognitive and language development and school achievement of children (Cabrera, Shannon, \& Tamis-Lemonda, 2007; Pancsofar \& VernonFeagans, 2010; Tamis-LeMonda, Baumwell, \& Cabrera, 2013). In addition, multiple studies have shown that fathers' interactions with their children are important for the development of empathy and social development in both 
sons and daughters (Leidy, Schofield, \& Parke, 2013). Furthermore, father's involvement is related to daughters' self-esteem (e.g., Keizer, Helmerhorst, \& Van Rijn-Van Gelderen, 2019). Finally, studies report that children have better physical and mental health when their fathers are actively involved in their lives (Carlson, 2006).

By being more involved in caregiving work, men also facilitate women's re-entry on the labor market. By increasing their involvement at home, their partners are able to return to the labor market sooner and for longer hours and therefore increase their labor market outcomes (Ory, 2019). The benefits of father's involvement may also reach beyond the individual household. A study finds that if women participated in the labor market at the same rates as men do, this would lead to an average increase in gross domestic product (GDP) of $12 \%$ by 2030 across the OECD countries (Thévenon, Ali, Adema, \& Salvi del Pero, 2012).

Father's stronger involvement in childcare may also have implications for how the next generation divides childcare responsibilities. According to the social cognitive theory of gender development (Bussey \& Bandura, 1999), children look to models in their environment for information about genderappropriate behavior. Parents who divide childcare responsibilities equally have children with more flexible attitudes about gender (Croft, Schmader, Block, \& Baron, 2014; Fulcher, Sutfin, \& Patterson, 2008), and daughters who are less vulnerable to gendered achievement patterns (Updegraff, Mchale, \& Crouter, 1996) and who aspire to less traditional roles (Croft et al., 2014). Men who have seen their own fathers engage in domestic work are themselves more likely to be involved in household work and caregiving as adults (Ory, 2019). In the following section, we will discuss child-related leave policies that set the rules for fathers' taking time off work to provide childcare.

\section{Father's Statutory Right to Care}

Across European countries, the right to care for small children is most often guaranteed through Labor and Social Security Codes. These legislations offer fathers a time off work to provide care and financial compensation for their foregone earnings while on leave. Depending on the country, fathers can draw their entitlements from maternity, paternity, and parental leaves. These policies differ primarily in the purpose for which they were introduced and in the intended recipient. The first leave policy-maternity leave, was introduced in Germany in 1883 (Kamerman \& Moss, 2009) and by 1919 it was recognized 
by the International Labour Organisation which formalized the minimum standards for maternity leave in its Maternity Protection Convention (ILO, 1919). Its main purpose then and now is to provide health, job, and income protection to pregnant working women and women recovering from childbirth. Although the maternity leave is primarily designed for mothers, in some countries, it can be transferred to the father in case the mother died or experienced complications during birth. More recently, some countries allowed mothers to transfer part of their maternity leave to fathers regardless of their health conditions (e.g., Czechia and Slovakia).

Parental leave was introduced several decades later. The first parental leave that allowed both parents to provide care for their young child was introduced in Sweden in 1974 (Sundström \& Stafford, 1992). In general, the purpose of parental leave is to provide care to a young child and is available to both parents after maternity leave (International Labour Organization, 2014). Paternity leave is the newest addition to the leave policies and was designed specifically for fathers to be taken around the time of birth of their child. The main purpose of paternity leave is to grant fathers leave from work to provide care and support for their partner and newborn child. Apart from the three main types of leave, fathers can be entitled to a leave when their child falls ill, and in a small number of countries they can apply for a socalled childcare or home care leave, which is an alternative for parents who wish to continue providing care for their children after parental leave instead of enrolling them in a formal childcare (Blum, Koslowski, Macht, \& Moss, 2018; OECD, 2017).

As Moss, Koslowski, and Duvander (2019) recently pointed out, there is a huge variation in leave designs across countries, which makes a meaningful comparison a challenging task. The great variation in the leave policies is primarily due to the differences in timing and motivations behind the introduction of these policies. It is important to remember that leave policies were created and modified in a response to a particular social, economic, and political needs of each country which inevitably affected their designs in a very specific way. For instance, in Czechoslovakia, the motivation behind the introduction of parental leave policies was to increase fertility which supposed to be achieved through an extended period of leave for mothers (Frejka, 1980). On the other hand, in Sweden, the introduction of parental leave policy was motivated by the achievement of greater gender equality in society (Duvander \& Johansson, 2012). This motivation set the country on a path of individual rights to leave for both parents and normalized the caring responsibilities of fathers over time. As a result, maternity, paternity, and parental leave policies can mean different things in different countries. By 
following the established categorization of leave policies into maternity, paternity, parental and childcare leave, we would substantially constrain the scope for a cross-national analysis of these policies and what they mean for mothers, fathers, and children across countries. Furthermore, the classification is also becoming increasingly inaccurate as more countries adopt leave policies that do not recognize such categories (e.g., Portugal, Iceland, Denmark, Norway, and Sweden).

We propose to abandon the potentially misleading classification of leave policies and to treat them as a blended or composite policy measure that combines leave entitlements for mothers, fathers, and parents. The advantage of this approach is in its ability to reach beyond the country-specific characteristics of leave policies. It allows to decompose the national policies and to create a clearer picture of the leave entitlements for parents across countries. In our chapter, we will refer to the composite leave policies as to child-related leave policies. We will focus on several important dimensions, which are characteristic for all leave designs, to analyze how the 13 European countries in our sample support the caring role of fathers.

\section{Dimensions of Child-Related Leave Policies and Their Implications for Fathers' Leave Uptake}

Each child-related leave policy in every country has several dimensions that are central to their designs. Their characteristics vary across countries and have implications for leave uptake and the share of leave between mothers and fathers. Moreover, these characteristics also have a wider implication for maternal employment, the gender wage gap, health outcomes, or child development (Chatterji \& Markowitz, 2012; Cukrowska-Torzewska, 2017; Galtry $\&$ Callister, 2005). There are four important dimensions of child-related leave policies that have implications for fathers' leave uptake-the type of entitlement, transferability, generosity, and flexibility.

The type of entitlement to child-related leave policies is either individual or family-based. In other words, the type of entitlements determines whether the leave is designed specifically for a mother or a father (individual entitlement) or whether it is intended for both parents to share according to their preferences (family entitlement). The type of entitlement applies to both time off work (leave) and to financial benefits for the time spent on leave. While maternity and paternity leave policies are usually accompanied by individual entitlements to financial compensation for foregone earnings, this is not the case for parental and childcare leave policies. In some countries, working parents are entitled to an individual right to parental leave but 
the financial benefits are based on family entitlement (e.g., France, Czechia). This means that although both parents could use parental leave at the same time, they would be entitled to only one benefit. Four combinations of entitlements to leave and benefits are possible: (1) an individual entitlement to leave with an individual entitlement to benefits, (2) individual entitlement to leave with a family entitlement to benefits, (3) family entitlement to leave with an individual entitlement to benefits, and (4) family entitlement to leave with a family entitlement to benefits.

Another important dimension is the transferability of leave entitlements. Since family entitlements are transferable entitlements by default, this condition only applies to individual entitlements. It determines whether one parent's leave entitlement can be transferred to the other parent (transferable) or whether the amount of leave dedicated to one parent will be lost if not claimed (non-transferable). The transferability applies to both time (leave) and financial benefits.

Flexibility is a dimension of child-related leave that refers to the freedom of choice parents have when deciding on when and how to use their leave entitlements. The flexibility is often determined by a time frame within which parents can use their entitlements. For instance, when fathers are entitled to five days of paternity leave which they need to use within four weeks following the birth of their child (The Netherlands). Another form of flexibility, that is characteristic for parental leave policies, is the regulation of the mode in which parents can use their entitlements-whether they must be used consecutively, whether both parents can use their entitlements at the same time, whether parents need to use their whole entitlement in one go or whether they can break it into several time blocks or take the leave on a part-time basis (e.g., one day a week).

The generosity of the financial benefits has for long been presented as a crucial for fathers' leave uptake. Although there is no consensus about the threshold below which fathers are not willing to use their leave entitlements, the general rule is the more generous the more attractive the prospect of childcare leave for fathers (Boll, Leppin, \& Reich, 2013). The financial benefits for the time spent on leave are either proportional to the earnings or paid as a flat-rate benefit. In the following section, we will discuss the implications these dimensions have for the uptake of the leave policies. 


\section{Leave Designs and Their Implications for Fathers' Leave Uptake}

The type and transferability of entitlements to child-related leave and the generosity of the financial benefits for fathers are exceptionally important for their leave uptake. Despite the rising numbers of caring fathers and working mothers, men's identity and the expectations society places on them are still largely associated with the labor market (Christiansen \& Palkovitz, 2001). In many countries, men and fathers are still often perceived by themselves or by others as providers who are responsible for ensuring financial stability for their family, and as ideal workers who are not constrained by their children's care needs (Lott \& Klenner, 2018). By granting fathers an individual nontransferable entitlement to child-related leave, countries recognize fathers as carers and equalize their caring responsibilities with those of mothers. The statutory entitlement to individual non-transferable leave also sends a signal to employers that they need to acknowledge the caring responsibilities of their male employees (Brandth \& Kvande, 2019). Moreover, the statutory entitlement to individual non-transferable leave strengthens fathers' negotiating position when requesting leave compared to requesting leave based on family entitlement (Haas \& Hwang, 2019; Moran and Koslowski, 2019). The individual non-transferable right to leave also gives fathers a stronger position in the home when negotiating the division of care with the mother (Närvi \& Salmi, 2019). At the same time, the importance of men's contribution to family income, which increases in families with lower socio-economic status, cannot be overlooked. There is a strong agreement in the international research that fathers are most likely to use their entitlements to child-related leave if they are based on an individual non-transferable entitlement that is accompanied by generous financial benefits (Boll et al. 2013).

Flexibility in the use of leave is a dimension of child-related leave policies that is rarely discussed but which may potentially have a strong implication for fathers' leave uptake. Flexibility is often determined by the difference between the duration of the leave entitlement and the time frame within which this entitlement has to be used. Flexibility is greater the larger is the time frame. The leave duration for each parent is most commonly defined by a specific time unit (hours, days, weeks, months) but in some countries the leave duration is determined by the age of the child for whom the parents draw their entitlements. This formulation of leave duration carries some characteristics typical of family-based entitlements. When it is paired with an individual non-transferable entitlement to leave, it transforms its meaning. It is because despite having an individual non-transferable entitlement, both 
parents are entitled to the same duration of leave within the same time frame. It means that parents need to negotiate who and when will take the leave. This design lacks the clear recognition of fathers' caring roles typical of nontransferable leave entitlements and may weaken fathers' negotiating position with their partners and employers. Therefore, apart from the type of entitlement, its transferability and the generosity of the financial benefits, we also need to consider how is the leave duration determined and what is the time frame within which can parents draw their entitlements. Child-related leave policies that (1) are based on individual non-transferable right to time off work, (2) come with generous financial benefits, and (3) that are defined in time units with extended time frame for uptake represent the leave designs that are likely to meet with the highest use among fathers.

\section{Data and Methodology}

To analyze the child-related leave policies, we use two sources of legislative information. One of the data sources is the 14th International Review of Leave Policies and Related Research 2018 (Blum et al., 2018) where we use the information on maternity, paternity, parental, and childcare leave. The second source of data is the Mutual Information System on Social Protection (MISSOC) database from which we use information on maternity and paternity leave (Section IV. Maternity/Paternity leave) and on parental leave and benefits (Section IX. Family Benefits) from the 1 July 2018 (2018-0701 update). Our analytical framework is based on the decomposition of maternity, paternity, parental, and childcare leave policies in individual European countries based on the dimensions of child-related leaves discussed in previous sections. The purpose of the policy decomposition process is to gain complete information on the fathers' rights to child-related leave regardless of the specific policy measure they can be drawn from in each country.

To analyze the fathers' child-related leave entitlements, we first pool maternity, paternity, parental, and childcare leaves in each country. We include maternity leave in our analysis because part of the leave may be transferable to the father. However, we recognize the transferable maternity leave as father's entitlement only if the transferability is not conditioned on the death or health conditions of the mother. In the second step, we differentiate between individual and family entitlements to child-related leave. In the third step, we look at the type of entitlement to financial benefitswhether they are based on an individual or family entitlement. As we already mentioned in the previous section, the combination of our third and fourth 
steps yields four categories of fathers' entitlements to child-related leave-(1) an individual non-transferable entitlement to leave for fathers with an individual entitlement to benefits, (2) individual transferable entitlement from mother to father with an individual entitlement to benefits, (3) individual non-transferable entitlement to leave with a family entitlement to benefits, and (4) family entitlement to leave with an individual entitlement to benefits. In the next step, we specify how many weeks of leave corresponds with each of the type of leave entitlement. In case of family entitlements to leave, we assign the total number of weeks of the family entitlement to the father. In the last step, we focus on the financial benefits associated with the leave. We break down the total entitlement to child-related leave for fathers into weeks and the generosity of the financial benefits. We use replacement rate to measure the generosity of child-related leave entitlement for fathers. This indicator shows the proportion of earnings that is replaced by the financial benefits.

During the operationalization process we came across several variations in policy designs that were not readily comparable across countries. First of all, when the duration of leave reserved for one or both parents was determined by the age of the child, we recalculated the total duration of this leave into the number of weeks. We calculated 52 weeks for each year of the child's age and from this number we subtracted the amount of postnatal leave that is reserved for mother (regardless of whether part of the postnatal leave for mother was transferable to the father or not). In case the leave duration was specified in the number of months, we recalculated this value into number of weeks ( 4.3 weeks in 1 month). Second, in some countries the financial benefits are provided as a flat-rate payment. In this case, we used Eurostat data on men's median monthly earnings in industry, construction, and services ${ }^{1}$ from 2014 , which is the most recent data currently available, to calculate the replacement rate. In countries where flat-rate benefits are granted based on income level (France), we use the basic benefit level to calculate the replacement rate. We use the most generous benefit in countries where parents can choose from different levels of flat-rate or income-related benefits.

Where available, we contrast the leave designs with fathers' use of leave. We source the data on leave uptake from the Annual Reviews produced by the International Network on Leave Policies and Research. ${ }^{2}$ Unfortunately, the data are limited and often collected in different years, which restrict their power for comparative analysis. Moreover, they tend to refer to a specific

\footnotetext{
${ }^{1}$ The data were collected from the "Structure of earnings survey: monthly earnings" (earn_ses_monthly).

${ }^{2}$ https://www.leavenetwork.org/annual-review-reports/country-reports/, accessed 17 December 2019.
} 
policy (e.g., paternity or parental leave) and the data on uptake are often unavailable for each of the leave in every country. Despite that, we decided to report this information alongside our analysis of child-related leave designs to consider possible differential impact on the fathers' leave uptake and to emphasize the need for better-quality data. In these cases, we always mention the type of leave policy the data refer to.

\section{Results}

Figure 15.1 plots the total amount of child-related leave entitlements for fathers broken down by their type. Overall, in the majority of the countries we study, fathers are entitled to relatively long leaves that exceed one year in duration. However, the Figure also reveals a considerable variation in the quality of leave entitlements for fathers across countries. Although fathers have access to individual non-transferable leave in almost all 13 countries, the length of the leave varies anywhere from 1 week in Czechia to 156 weeks in Spain and Slovakia. Only Slovak fathers have not gained access to individual non-transferable leave. Nonetheless, this may change soon since the European Union Directive on work-life balance for parents and carers came into effect in 2019. The Directive requires all Member States to introduce policies

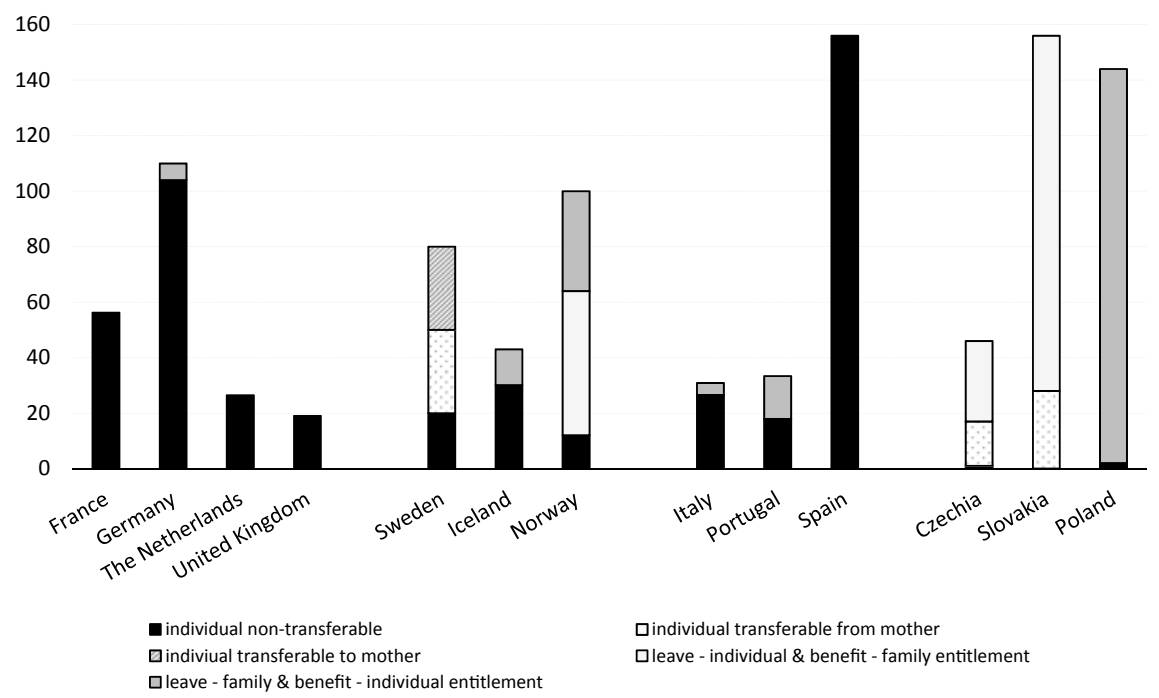

Fig. 15.1 Distribution of leave entitlements to child-related leave for fathers (in weeks), 2018 (Note Based on authors' own calculations. Source 14th International Review of Leave Policies and Related Research 2018; MISSOC 2018-07-01) 
that grant fathers with at least 10 working days of individual non-transferable right to paternity leave.

The second most common type of leave for fathers is based on family entitlement to leave and individual entitlement to financial benefit. We found this type of entitlement in Germany, Poland, Portugal, Iceland, and Norway. The remaining types of child-related leave entitlements are much less common. We found the individual entitlement to leave with family entitlement to benefits only in Czechia, Slovakia, and Norway. Mothers are allowed to transfer some of their entitlements to fathers in Sweden, Czechia, and Slovakia. Finally, Sweden is the only country in our sample that allows fathers to transfer some of their individual leave entitlement to mothers. The empirical evidence shows that fathers are more likely to use their individual non-transferable leave if it is paired with sufficiently high financial compensation (Boll et al., 2013). Figure 15.2 shows the distribution of financial compensation for fathers across the total amount of their leave entitlements in cross-country comparison. The data reveal considerable variation in the value countries place on fathers' time on childcare. Fathers are not guaranteed any statutory financial compensation for a considerable share of their leave entitlements in 5 out of the 13 countries.

We identified two distinct approaches to leave entitlements for fathers(1) leave with dominant individual non-transferable rights and (2) leave

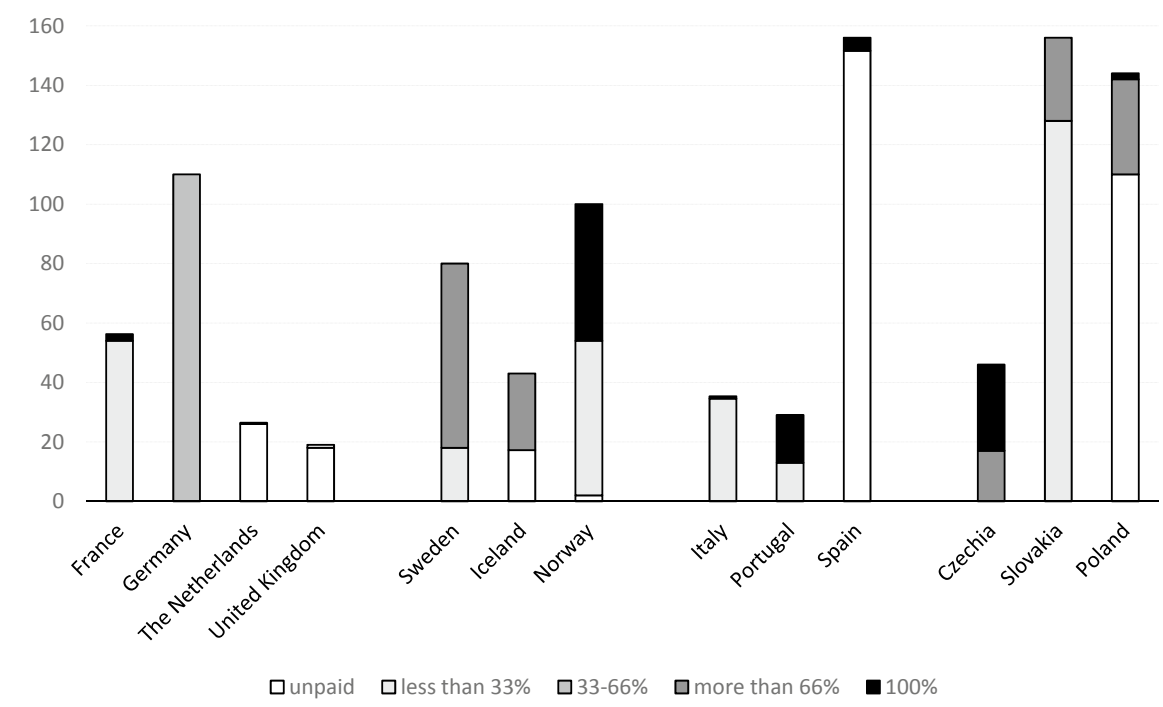

Fig. 15.2 Distribution of financial compensation across the total leave entitlements (in weeks), 2018 (Note Based on authors' own calculations. Source 14th International Review of Leave Policies and Related Research 2018; MISSOC 2018-07-01) 
composed of several different types of entitlements. The first type is strong in Western and Southern European countries. The second type, on the other hand, is prevalent in Northern and Central and Eastern European countries. However, we also identified variations in these two main approaches to leave for fathers. Among the countries with composite leave entitlements, Sweden, Iceland, and Norway provide fathers with generously compensated individual non-transferable right to leave. In contrast, among the countries with strong emphasis on individual non-transferable leave entitlements, Germany, Portugal, and Italy offer additional months of leave which vary in the type of entitlement and generosity. We capture this variation in dividing the analyzed countries into four groups: countries with dominant individual non-transferable leave entitlements, countries with dominant individual nontransferable leave entitlements and additional incentives for fathers, countries with composite child-related leave entitlements and strong father's quota, and countries with composite child-related leave entitlements and limited father's quota.

\section{Countries with Dominant Individual Non-Transferable Leave Entitlements}

The countries where fathers are solely entitled to individual non-transferable leave are Spain, The Netherlands, The United Kingdom (UK), and France. In Spain, where we found the longest individual non-transferable leave entitlement, fathers are fully compensated for only 4.4 weeks of leave. The remaining 151.6 weeks are without a statutory guarantee of financial benefits. The situation is similar for fathers in The Netherlands and the United Kingdom. In The Netherlands in 2018, fathers were fully compensated only for 0.4 weeks of their leave entitlements and the remaining 26 weeks were without a statutory guarantee of financial benefits. In contrast, fathers in the UK are not fully compensated for any part of their leave entitlements. They are entitled to financial benefit that corresponds with about $18 \%$ of their earnings and that is only for one week of their total entitlements. For the rest of their leave entitlements, they are not guaranteed any financial compensation. In France, where fathers are offered 56.2 weeks of individual non-transferable child-related leave, they are fully compensated for only 2.2 weeks of this entitlement. For the remaining duration of their leave entitlement, fathers are entitled to financial benefits that correspond with about $17 \%$ of their earnings.

When we look at fathers' leave uptake, we can identify some patterns in the fathers' preferences for well-compensated leave entitlements over unpaid or 
poorly compensated leave that have been described in the literature. In 2012, $74 \%$ of Spanish fathers took at least some of their 4.4 weeks of fully paid leave (Meil, Lapuerta, \& Escobedo, 2018). However, the remaining share of the leave that corresponds with parental leave entitlements has generally very low uptake both among women and men. In 2016, only $9.9 \%$ of all parents took some parental leave and out of this $9.9 \%$, about $93 \%$ were mothers and about 7\% were fathers (ibid.). In France in 2016, 62\% of fathers used their entitlement to the fully paid leave (Boyer \& Fagnani, 2018). Out of all users of the remaining share of leave, which is also available to mothers, only $4.4 \%$ were fathers (ibid.). The situation is similar in The Netherlands where $83 \%$ of fathers took the fully paid leave entitlement ( 0.4 weeks) in 2013 but only $11 \%$ of fathers took some of the remaining leave entitlement that is not accompanied with a statutory guarantee of financial benefit (Den Dulk, 2018). However, it is important to point out that some Dutch employers offer financial compensation for this type of leave, which is likely to influence the statistics on leave uptake. This is the case also in the UK, where in 2006 about $30 \%$ of fathers took at least some of their leave entitlements without a statutory guarantee to financial compensation. Out of the $30 \%$, about $17 \%$ of fathers were fully compensated for their time on leave, $6 \%$ were partially compensated and $7 \%$ of these fathers took unpaid leave (O'Brien \& Koslowski, 2018). About $74 \%$ of fathers in the UK took at least some of their one-week entitlement to paid leave (O’Brien \& Koslowski, 2018).

Although the uptake of unpaid leave entitlements is low, fathers do not necessarily withdraw from participation in childcare. This is particularly true for the period around the time of birth. The Netherlands and the UK are good examples of fathers adopting alternative strategies to provide support to their families. In these countries, a considerable number of fathers opt for using their annual leave either as the sole source of leave around the time of birth or as an additional leave to their statutory child-related leave entitlements. In the UK in $2009,18 \%$ of fathers who took any form of leave opted for other forms of paid leave than their child-related leave entitlements (e.g., annual leave) and 25\% used both their entitlements to child-related leave and some other form of leave entitlements (O’Brien \& Koslowski, 2018). In The Netherlands, in 2013 , about $60 \%$ of fathers who used their entitlements to the fully paid child-related leave also used some of their annual leave around the time of birth (Den Dulk, 2018). 


\section{Countries with Composite Child-Related Leave Entitlements and Strong Father's Quota}

The Nordic countries in our sample (Sweden, Norway, and Iceland) are countries that have composite leave entitlements and provide strong incentive for fathers' leave uptake. Sweden is the only country in the whole sample with composite leave entitlements that does not provide family entitlement either to leave or to financial benefits. Swedish fathers are entitled to 20 weeks of individual non-transferable leave, 30 weeks of leave that can be transferred to the mother, and an additional 30 weeks that mother can transfer to the father. In total, Swedish fathers can spend up to 80 weeks with their small child. They are offered financial benefits that compensate for $78 \%$ of their earnings for the majority of their leave ( 62 weeks). For the remaining period, they are entitled to financial benefits that correspond with about $11 \%$ of their earnings. In 2004 , about $88 \%$ of Swedish fathers took at least some child-related leave but according to data from 2008, fathers on average took 106 days of leave, which corresponds with about 21.2 working weeks (Duvander \& Haas, 2018). This is only slightly more than the 20 weeks of their individual nontransferable entitlement, which can mean either that fathers take some of the entitlements that can be transferred to their partner or that some fathers work more than 5 days a week. ${ }^{3}$ Nonetheless, the statistics on fathers' leave uptake suggests that the fathers tend to use only their individual non-transferable entitlement and they transfer the rest to their partner (in 2008, mothers took on average 342 days, or 68.4 weeks) (ibid.).

We can observe similar outcomes in Iceland and Norway. In Iceland, fathers are provided with 30.1 weeks of individual non-transferable right to leave. However, they are relatively generously compensated $(85 \%)$ only for 12.9 weeks and the remaining 17.2 weeks are unpaid. Fathers are also eligible to 12.9 weeks of family entitlement to leave with an individual entitlement to benefits paid at $85 \%$ replacement rate. Data from 2015 show that $81 \%$ of fathers used at least some of their child-related leave entitlements and on average, they took 88 days (17.6 weeks). However, $34.3 \%$ of fathers took less than the 12.9 weeks of their individual non-transferable leave, and only $13.3 \%$ of fathers took some of the family entitlement to leave (Eydal \& Gíslason, 2018). In Norway, fathers are entitled to 10 weeks of individual non-transferable leave that is fully compensated and to 2 weeks of individual non-transferable leave that is not accompanied by any financial

\footnotetext{
${ }^{3}$ We used 5-day working week to recalculate the 106 days into weeks. If we were to calculate 6 days or 7 days working weeks, the transformation into weeks would yield a lower number than 21.2 weeks.
} 
benefits. Apart from that, they are also entitled to 36 weeks of family entitlement to leave with individual entitlement to benefits (100\% replacement rate), and to 52 weeks of individual entitlement to leave with a family entitlement to benefits (about 14\% replacement rate). The statistics on the use of leave by Norwegian fathers are not regular but the uptake is reported to vary between 70 and 90\% (Brandth \& Kvande, 2018). The uptake is therefore very similar to those observed in Sweden and Iceland. In 2014, fathers who used some child-related leave took on average 49 days (9.8 weeks), which again corresponds with the individual non-transferable entitlement to leave (ibid.).

\section{Countries with Composite Child-Related Leave Entitlements and Limited Father's Quota}

The remaining countries with composite child-related leave entitlements for fathers who offer only limited incentives for fathers' leave uptake are Czechia, Slovakia and Poland. In Czechia, fathers gained individual non-transferable entitlement to leave only in February 2018 (1 week). Apart from that, Czech fathers are entitled to about 29 weeks of individual entitlement to leave with family entitlement to benefits which compensates for up to $100 \%$ earnings, ${ }^{4}$ and to 16 weeks of individual transferable leave from mother $(70 \%$ replacement rate). In 2018, 43,442 fathers used their entitlements to the one week of individual non-transferable leave (Kocourková, 2018), which corresponds with about $38 \%$ of all births in that year. The uptake of the individual entitlement to leave with family entitlement to benefits varies between 1 and 2\% (ibid.). In Slovakia, fathers are only entitled to 28 weeks that can be transferred from mother and these compensate for $75 \%$ of earnings. In addition, they are also entitled to 128 weeks of individual entitlement to leave and family entitlement to benefits (about 26\% replacement rate). According to existing data, in 2017 , only about $7 \%$ of all recipients of maternity leave were men (Gerbery, 2018). Unfortunately, data on the uptake of the individual leave entitlement with family entitlement to benefits are not available. In Poland, fathers are entitled to two weeks of fully compensated individual non-transferable leave and to 142 weeks of family entitlement to leave with

\footnotetext{
${ }^{4}$ Parents are entitled to 220,000 CZK over a period of 4 years. Parents can choose freely the duration of leave, which determines the amount of benefits they receive every month. The maximum benefit parents can draw is $32,640 \mathrm{CZK}$ (about $€ 1.263$ ) that can be drawn over a period of 29 weeks. The maximum amount of monthly benefit payment is higher than the median monthly salary in Industry, Construction and Services in 2014 (€851). We, therefore, used $100 \%$ replacement rate to mark the generosity of the maximum benefits.
} 
individual entitlement to benefits. Out of the 142 weeks, for 32 weeks are Polish fathers entitled to $80 \%$ of their earnings but the remaining 110 weeks are unpaid (small financial benefit is available to families with very low income). In 2017, 174,200 fathers used their individual non-transferable entitlement to leave, which represents about $43 \%$ of all births in that year, and used 12.6 days of leave on average (Kurowska, Michoń, \& GodlewskaBujok, 2018). The uptake of the remaining leave entitlements is about $1 \%$ (ibid.).

\section{Countries with Dominant Individual Non-Transferable Leave Entitlements and Incentives for Fathers}

Three countries with individual non-transferable entitlements (Germany, Portugal, and Italy) provide incentives to increase fathers' uptake of childrelated leave entitlements which are distinct from the father's quota observed in the Nordic countries. These incentives are referred to as bonus months. This means that if fathers take a specific amount of child-related leave, the total amount of leave available per child, or per family, is extended by a certain number of months. The bonus months are a particularly interesting characteristic of child-related leave entitlements because they try to mimic the success of father's quotas in Nordic countries through distinct policy design. Although all three countries adopted bonus months in their leave designs, each did it in their own way. We will now look more closely at this feature in the three countries and will discuss how successful they are in encouraging fathers use of child-related leave entitlements.

In Italy, fathers are entitled to 26.6 weeks of individual non-transferable leave but only 0.8 weeks are fully compensated (paternity leave). The remaining 25.8 weeks are compensated at $30 \%$ of earnings. Both father and mother are entitled to 25.8 weeks of individual non-transferable leave (parental leave) but they can only use 43 weeks of leave entitlements per child. It means that although the leave entitlements are individual and nontransferable, parents still need to negotiate who and when will take the leave because the total allowed leave duration is shorter than the sum of the individual entitlements of both parents. Therefore, although the leave design is based on an individual non-transferable entitlement, it carries characteristics that are typical for family-based entitlements. To encourage fathers' uptake of child-related leave, Italy introduced a condition that guarantees the family additional 4.3 weeks (i.e., bonus month) if the father takes at least 12.9 weeks of his entitlement. However, the bonus month does not specify who is it intended for, which makes it a family entitlement. 
At the beginning of our chapter, we argued that flexibility in leave duration and the length of the time frame within which parents can use their leave entitlements is crucial for fathers' uptake of child-related leave policies. A time frame that is as long as the total leave entitlement of both parents, or is shorter than the total leave entitlement, transforms the individual non-transferable leave into a family entitlement. This is because the limited flexibility in leave use is forcing parents to negotiate their leave. We also expected that the leave policies with such designs will meet with low uptake among fathers. We found some support for this argument, although our analysis cannot directly link the data with the bonus month. In 2016, out of all parental leave recipients in Italy, only 17\% were fathers (Addabbo, Cardinali, Giovannini, \& Mazzucchelli, 2018).

Germany is somewhat a special case among the countries with dominant individual non-transferable entitlements to leave. It is because German fathers are entitled to an individual non-transferable right to leave and to benefits that are proportional to their income $(65 \%)$ until their child is two years old. This entitlement is also available to mothers. However, the framing of the leave duration based on the child's age transforms the leave design into a hybrid between individual and family entitlement to leave. This is because each parent does not have a specifically allocated time for leave but instead have to negotiate with the other parent when and how long a leave to take, although taking the leave simultaneously is also a possibility. If both parents use at least two months of leave, the family is provided with two additional months of leave. As in Italy, the law does not specify who are these bonus months intended for, which, strictly speaking, makes it a family entitlement. Even though the bonus months are not specifically designed for fathers, the information on leave uptake suggests that the majority of fathers who took some child-related leave did not take more than two months $(78.9 \%$ of male recipients in 2016) (Reimer, Erler, \& Blum, 2018). However, in 2014 only $35.7 \%$ of fathers used their leave entitlements.

Finally, in Portugal, fathers are entitled to 17.9 weeks of individual nontransferable leave but only 5 weeks of this entitlement are fully compensated. The remaining 12.9 weeks compensate for $25 \%$ of fathers' earnings. Apart from that, fathers are entitled to 11.4 weeks of family entitlement to leave with individual entitlement to benefits (100\% replacement rate). In case, fathers use at least 4 weeks out of this family entitlement, the family is entitled to an additional 4 weeks of leave (i.e., bonus month). In 2017, about $71 \%$ of fathers took the 5 weeks of individual non-transferable leave that is fully compensated. However, only about $34 \%$ of families received the bonus month and the vast majority of fathers took no more than one month of 
the family entitlement to child-related leave (Wall \& Leitão, 2018). This is somewhat surprising because the financial compensation for fathers' leave is exceptionally generous in cross-national comparison. It suggests that neither generous financial benefits may be successful in raising fathers' use of leave policies if the generous benefits are not associated with an individual nontransferable right to leave. This is also supported by the statistic on uptake of the 12.8 weeks of individual non-transferable entitlement that compensates only $25 \%$ of earnings-only $8 \%$ of all parents used this entitlement in 2017 (Wall \& Leitão, 2018).

\section{Conclusion}

In this chapter, we aimed to analyze how contemporary family policies in Europe support caregiving role of fathers. We found support for the notion that generous individual non-transferable leave entitlement is the most stimulating form of leave design for fathers' use of child-related leave. Although all countries offer fathers an individual non-transferable entitlement to child-related leave, the policies in the majority of the countries do not sufficiently challenge the gendered distribution of paid and unpaid work. The individual non-transferable leave entitlements are still very limited in Central and Eastern European countries (Czechia, Slovakia and Poland). However, in countries where fathers are entitled to much longer individual non-transferable child-related leaves, they are fully compensated only for a fraction of this entitlement, which negatively impacts on their leave uptake (e.g., The Netherlands, France, Portugal). In many countries, fathers are still not provided with any statutory guarantee of financial compensation for a substantial share of their individual non-transferable entitlements to child-related leave (The Netherlands, the UK, Spain, Poland). The less compensated child-related leave, the more it produces polarized behaviors among parents, mostly based on social class or education (Korpi, 2000; Saraceno, 2011). Without statutory guarantee of financial compensation, mainly fathers from higher social classes are capable to take short periods of (part-time) leave. In line with this idea, research has shown that throughout developed countries, higher educated fathers are more involved in childcare and are more likely to take up paternity leave (Boll et al., 2013; Geisler \& Kreyenfeld, 2018). Differences in father involvement by social class may contribute to widening social-class disparities in children's resources and development. A child-related leave that is accompanied by generous financial benefits has the potential to equalize the leave uptake among fathers 
with different socio-economic background and consequently lead to fewer social-class disparities in children's resources and development.

We also pointed out the importance of flexibility, a rarely discussed component of child-related leaves, and the way policy designs frame the entitlements to leave duration. We found some evidence that these components may have an important effect on fathers' use of their leave entitlements. Although the generously compensated individual non-transferable leaves are the most attractive for fathers, their value seems to decrease with inaccurately formulated duration of leave and the time frame within which can parents use their leave. When both parents are entitled to an individual non-transferable leave, but the total amount of leave they may use per family is shorter than the sum of their individual entitlements, the individual non-transferable leave starts to resemble the leave that is based on a family entitlement. It is because both of the parents cannot use their full entitlements and have to negotiate when and how they will use the leave. Similarly, when the individual entitlement to leave is determined by child's age, the fathers not only have to negotiate with their partners, but they also lose on their negotiating position with their employer because their own leave entitlement is not clearly specified by law.

In some European countries, policymakers attempted to increase leave uptake among fathers through so-called bonus months. This measure provides a family with extra months of leave if both of the parents take a certain amount of leave. However, this incentive has not managed to achieve the success of father's quotas in Nordic countries, which they tried to mimic. In Northern Europe, the uptake of individual non-transferable entitlements hovers around $80 \%$, while in countries that introduced the bonus month the uptake has not been higher than 35\%. This difference may be partially explained by the cultural differences between the countries. While Nordic countries have a strong tradition of promoting gender equality, Germany, Portugal, and Italy are countries with rather a traditional approach to family and gender roles. However, the staggering difference is also likely to be caused by the design of the bonus months that are not built on an individual non-transferable right to child-related leave. For instance, the bonus months in Germany were already introduced in 2007, yet ten years later only $35.7 \%$ of fathers used parental leave. In contrast, in Norway the father's quota was introduced in 1993. Before that only about 3\% of Norwegian fathers used some entitlement to parental leave. However, only seven years after the introduction the fathers' uptake of parental leave rose to $85 \%$ (Brandth \& Kvande, 2019). Therefore, individual non-transferable leave entitlements that clearly specify the period of leave are crucial for the fathers' leave uptake. Generous financial compensation for the time spent 
on childcare is particularly important for leave uptake among fathers with lower socio-economic status. Nonetheless, the use of child-related leave policies by fathers is also likely to be shaped by the gender norms dominant in individual countries irrespective of the quality of their policy entitlements. On the other hand, institutional support for caring role of fathers normalizes fathers' active involvement in childcare, which itself may encourage shifts in common gender norms.

Finally, it is important to point out that the European landscape of fathers' child-related leave entitlements will likely change in the following years in response to the Work-Life Balance Directive. ${ }^{5}$ The Directive requires all Member States to provide at least 10 working days of paternity leave and 4 months of individual leave for working parents out of which 2 months must be non-transferable. However, the financial compensation for the time spent on leave is left entirely in hands of the Member States. In consequence, the extent of the potential impact is debatable. Our results revealed that individual non-transferable entitlements to leave are common in all countries in our sample with the exception of the Central and Eastern European countries. Therefore, we expect that the new requirements on parental leave will primarily affect these countries but will trigger no to limited change in the remaining countries in our sample. We can expect more changes in paternity leaves. We expect paternity leave to be introduced in Germany and Slovakia in the coming years, and extensions to existing paternity leave in The Netherlands, Italy, and Czechia. The introduction of the Work-life Balance Directive certainly raises a question of how countries with individual leave entitlements framed by the age of child will deal with the condition of non-transferable entitlement for each parent. This also applies to countries with individual entitlement to leave and a time frame which prevents both parents from using their full individual entitlements. The condition of non-transferability can potentially lead to adjustments in the specification of leave duration in countries like Germany, which could increase fathers' bargaining power and ultimately lead to greater use of leave entitlements among fathers. On the other hand, most of the countries in our sample already have individual entitlements to leave in place without any reference to transferability. From a legal point of view, it can be argued that the conditions of the Directive concerning non-transferability of parental leave have already been fulfilled. In such case, the impact of the Directive on fathers' use of their leave entitlements will be severely limited.

\footnotetext{
${ }^{5}$ Directive 2019/1158 of the European Parliament and of the Council of 20 June 2019 on work-life balance for parents and carers.
} 
Acknowledgements The present study was supported by a grant from the Netherlands Organization for Scientific Research (NWO MaGW VIDI; grant no. 45217-005) and by a grant from the European Research Council (ERC StG; grant no. 757210).

\section{References}

Addabbo, T., Cardinali, V., Giovannini, D., \& Mazzucchelli, S. (2018). Italy country note. In S. Blum, A. Koslowski, A. Macht, \& P. Moss (Eds.), International review of leave policies and research 2018 (pp. 223-240).

Blum, S., Koslowski, A., Macht, A., \& Moss, P. (2018). 14th international review of leave policies and related research 2018.

Boll, C., Leppin, J., \& Reich, N. (2013). Paternal childcare and parental leave policies: Evidence from industrialized countries. Review of Economics of the Household, 12(1), 129-158.

Boyer, D., \& J. Fagnani. (2018). France country note. In S. Blum, A. Koslowski, A. Macht, \& P. Moss (Eds.), International review of leave policies and research 2018 (pp. 171-176).

Brandth, B., \& Kvande, E. (2018). Norway country note. In S. Blum, A. Koslowski, A. Macht, \& P. Moss (Eds.), International review of leave policies and research 2018 (pp. 313-322).

Brandth, B., \& Kvande, E. (2019). Workplace support of fathers' parental leave use in Norway. Community, Work and Family, 22(1), 43-57.

Bussey, K., \& Bandura, A. (1999). Social cognitive theory of gender development and differentiation. Psychological Review, 106(4), 676-713.

Cabrera, N. J., Fagan, J., \& Farrie, D. (2008). Explaining the long reach of father' prenatal involvement on later paternal engagement. Journal of Marriage and Family, 70(5), 1094-1107.

Cabrera, N. J., Fitzgerald, H. E., Bradley, R. H., \& Roggman, L. (2014). The ecology of father-child relationships: An expanded model. Journal of Family Theory \& Review, 6(4), 336-354.

Cabrera, N. J., Shannon, J. D., \& Tamis-Lemonda, C. (2007). Fathers' influence on their children's cognitive and emotional development: From toddlers to pre-K. Applied Development Science, 11(4), 208-213.

Cabrera, N. J., Tamis-LeMonda, C. S., Bradley, R. H., Hofferth, S., \& Lamb, M. E. (2000). Fatherhood in the twenty-first century. Child Development, 71(1), 127136.

Carlson, D. L., Hanson, S., \& Fitzroy, A. (2016). The division of child care, sexual intimacy, and relationship quality in couples. Gender \& Society, 30(3), 442-466.

Carlson, M. J. (2006). Family structure, father involvement, and adolescent behavioral outcomes. Journal of Marriage and Family, 68(1), 137-154. 
Chatterji, P., \& Markowitz, S. (2012). Family leave after childbirth and the mental health of new mothers. Journal of Mental Health Policy and Economics, 15, 61-76.

Christiansen, S. L., \& Palkovitz, R. (2001). Why the 'good provider' role still matters: Providing as a form of paternal involvement. Journal of Family Issues, 22(1), 84-106.

Croft, A., Schmader, T., Block, K., \& Baron, A. S. (2014). The second shift reflected in the second generation: Do parents' gender roles at home predict children's aspirations? Psychological Science, 25(7), 1418-1428.

Cukrowska-Torzewska, E. (2017). Cross-country evidence on motherhood employment and wage gaps: The role of work-family policies and their interaction. Social Politics: International Studies in Gender, State \& Society, 24(2), 178-220.

Dermott, E., \& Miller, T. (2015). More than the sum of its parts? Contemporary fatherhood policy, practice and discourse. Families, Relationships and Societies, 4(2), 183-195.

Doucet, A. (2013). Gender roles and fathering. In N. J. Cabrera \& C. S. TamisLeMonda (Eds.), Handbook of father involvement (pp. 297-319). New York, NY: Taylor \& Francis.

Den Dulk, L. (2018). Netherlands country note. In S. Blum, A. Koslowski, A. Macht, \& P. Moss (Eds.), International review of leave policies and research 2018 (pp. 295-305).

Duvander, A.-Z., \& Haas, L. (2018). Sweden country note. In S. Blum, A. Koslowski, A. Macht, \& P. Moss (Eds.), International review of leave policies and research 2018 (pp. 401-410).

Duvander, A.-Z., \& Johansson, M. (2012). What are the effects of reforms promoting fathers' parental leave use? Journal of European Social Policy, 22(3), 319-330.

Eydal, G. B., \& Gíslason, I. V. (2018). Iceland country note. In S. Blum, A. Koslowski, A. Macht, \& P. Moss (Eds.), International review of leave policies and research 2018 (pp. 205-211).

Fagan, J., Day, R., Lamb, M. E., \& Cabrera, N. J. (2014). Should researchers conceptualize differently the dimensions of parenting for fathers and mothers? Journal of Family Theory \& Review, 6 (4), 390-405.

Frejka, T. (1980). Fertility trends and policies: Czechoslovakia in the 1970s. Population and Development Review, 6(1), 65-93.

Fulcher, M., Sutfin, E. L., \& Patterson, C. J. (2008). Individual differences in gender development: Associations with parental sexual orientation, attitudes, and division of labor. Sex Roles, 58, 330-341.

Galtry, J., \& Callister, P. (2005). Assessing the optimal length of parental leave for child and parental well-being: How can research inform policy? Journal of Family Issues, 26 (2), 219-246.

Geisler, E., \& Kreyenfeld, M. (2018). Policy reform and fathers' use of parental leave in Germany: The role of education and workplace characteristics. Journal of European Social Policy, 29(2), 273-291. 
Gerbery, D. (2018). Slovak Republic country note. In S. Blum, A. Koslowski, A. Macht, \& P. Moss (Eds.), International review of leave policies and research 2018 (pp. 373-378).

Grossmann, K., Grossmann, K. E., Fremmer-Bombik, E., Kindler, H., ScheuererEnglisch, H., \& Zimmermann, P. (2002). The uniqueness of the child-father attachment relationship: Fathers' sensitive and challenging play as a pivotal variable in a 16-year longitudinal study. Social Development, 11(3), 301-337.

Grunow, D., \& Evertsson, M. (Eds.). (2019). New parents in Europe. Cheltenham: Edward Elgar.

Grunow, D., \& Evertsson, M. (Eds.). (2016). Couples' transitions to parenthood: Analysing gender and work in Europe. Cheltenham: Edward Elgar.

Haas, L., \& Hwang, C. P. (2019). Policy is not enough-The influence of the gendered workplace on fathers' use of parental leave in Sweden. Community, Work and Family, 22(1), 58-76.

Hook, J. L. (2006). Care in context: Men's unpaid work in 20 countries, 19652003. American Sociological Review, 71(4), 639-660.

ILO. (1919). Maternity protection convention. Washington, DC.

International Labour Organization. (2014). Maternity and paternity leave: Law and practice across the world.

Kamerman, S., \& Moss, P. (2009). The politics of parental leave policies: Children, parenting, gender and the labour market (S. Kamerman \& P. Moss, Ed.). Bristol, UK and Portland, OR: Policy.

Kan, M. Y., Sullivan, O., \& Gershuny, J. (2011). Gender convergence in domestic work: Discerning the effects of interactional and institutional barriers from largescale data. Sociology, 45(2), 234-251.

Keizer, R., Dykstra, P. A., \& Van Lenthe, F. J. (2011). Parity and men's mortality risks. European Journal of Public Health, 22(3), 343-347.

Keizer, R., Dykstra, P. A., \& Poortman, A.-R. (2009). Life outcomes of childless men and fathers. European Sociological Review, 26 (1), 1-15.

Keizer, R., Helmerhorst, K. O. W., \& Van Rijn-Van Gelderen, L. (2019). Perceived quality of the mother-adolescent and father-adolescent attachment relationship and adolescents' self-esteem. Journal of Youth and Adolescence, 48, 1203-1217.

Knoester, C., \& Eggebeen, D. J. (2006). The effects of the transition to parenthood and subsequent children on men's well-being and social participation. Journal of Family Issues, 27(11), 1532-1560.

Kocourková, J. (2018). Czech Republic country note. In S. Blum, A. Koslowski, A. Macht, \& P. Moss (Eds.), International review of leave policies and research 2018 (pp. 127-132).

Korpi, W. (2000). Faces of inequality: Gender, class, and patterns of inequalities in different types of welfare states. Social Politics, 7(2), 127-191.

Kotsadam, A., \& Finseraas, H. (2011). The state intervenes in the battle of the sexes: Causal effects of paternity leave. Social Science Research, 40(6), 1611-1622. 
Kurowska, A., Michoń, P., \& Godlewska-Bujok, B. (2018). Poland country note. In S. Blum, A. Koslowski, A. Macht, \& P. Moss (Eds.), International review of leave policies and research 2018 (pp. 323-331).

Lamb, M. E. (2010). How do fathers influence children's development? Let me count the ways. In M. E. Lamb (Ed.), The role of the father in child development (pp. 1-27). Hoboken, NJ: Wiley.

Lamb, M. E., \& Lewis, C. (2013). Father-child relationships. In N. J. Cabrera \& C. S. Tamis-Le-Monda (Eds.), Handbook of father involvement: Multidisciplinary perspectives (pp. 119-134). New York, NY: Routledge.

LaRossa, R. (1997). The modernization of fatherhood. Chicago: University of Chicago.

Leidy, M. S., Schofield, T. J., \& Parke, R. D. (2013). Father's contributions to children's social development. In N. J. Cabrera \& C. S. Tamis-Le-Monda (Eds.), Handbook of father involvement: Multidisciplinary perspectives (pp. 151-167). New York, NY: Routledge.

Levtov, R., Van der Gaag, N., Greene, M., Kaufman, M., \& Barker, G. (2015). State of the world's fathers: A men care advocacy publication. Washington, DC: Promundo, Rutgers, Save the Children, Sonke Gender Justice, and the MenEngage Alliance.

Lott, Y., \& Klenner, C. (2018). Are the ideal worker and ideal parent norms about to change? The acceptance of part-time and parental leave at German workplaces. Community, Work and Family, 21(5), 564-580.

Maume, D. (2010). Reconsidering the temporal increase in fathers' time with children. Journal of Family and Economic Issues, 32, 411-423.

Meil, G., Lapuerta, I., \& Escobedo, A. (2018). Spain country note. In S. Blum, A. Koslowski, A. Macht, \& P. Moss (Eds.), International review of leave policies and research 2018 (pp. 387-400).

Moran, J., \& Koslowski, A. (2019). Making use of work-family balance entitlements: How to support fathers with combining employment and caregiving. Community, Work and Family, 22(1), 111-128.

Moss, P., Koslowski, A., \& Duvander, A.-Z. (2019). Introduction: Much work still to do. In P. Moss, A.-Z. Duvander, \& A. Koslowski (Eds.), Parental leave and beyond: Recent international developments, current issues and future directions. Bristol: Policy Press.

Närvi, J., \& Salmi, M. (2019). Quite an encumbrance? Work-related obstacles to finnish fathers' take-up of parental leave. Community, Work and Family, 22(1), 23-42.

O’Brien, M., \& Koslowski, A. (2018). United Kingdom country note. In S. Blum, A. Koslowski, A. Macht, \& P. Moss (Eds.), International review of leave policies and research 2018 (pp. 423-436).

OECD. (2017). PF2.1: Key Characteristics of Parental Leave Systems.

Ory, B. (2019). Drivers and barriers of involved fatherhood: Family characteristics, social class, and country context. Rotterdam: Erasmus University Rotterdam. 
Pancsofar, N., \& Vernon-Feagans, L. (2010). Fathers' early contributions to children's language development in families from low-income rural communities. Early Childhood Research Quarterly, 25, 450-463.

Paquette, D. (2004). Theorizing the father-child relationship: Mechanisms and developmental outcomes. Human Development, 47(4), 193-219.

Plantin, L., Olukoya, A. A., \& Ny, P. (2011). Positive health outcomes of fathers' involvement in pregnancy and childbirth paternal support: A scope study literature review. Fathering, 9(1), 87-102.

Raley, S., Bianchi, S. M., \& Wang, W. (2012). When do fathers care? Mothers' economic contribution and fathers' involvement in child care. American Journal of Sociology, 117(5), 1422-1459.

Reimer, T., Erler, D., \& Blum, S. (2018). Germany country note. In S. Blum, A. Koslowski, A. Macht, \& P. Moss (Eds.), International review of leave policies and research 2018 (pp. 177-187).

Risman, B. J., \& Johnson-Sumerford, D. (1998). Doing it fairly: A study of postgender marriages. Journal of Marriage and the Family, 60(1), 23.

Saraceno, C. (2011). Childcare needs and childcare policies: A multidimensional issue. Current Sociology, 59(1), 78-96.

Sarkadi, A., Kristiansson, R., Oberklaid, F., \& Bremberg, S. (2008). Fathers' involvement and children's developmental outcomes: A systematic review of longitudinal studies. Acta Paediatrica, 97(2), 153-158.

Sigle-Rushton, W., Goisis, A., \& Keizer, R. (2012). Fathers and fatherhood in the European Union. In N. J. Cabrera \& C. S. Tamis-LeMonda (Eds.), Handbook of father involvement (pp. 81-96). New York: Taylor \& Francis.

Sundström, M., \& Stafford, F. P. (1992). Female labour force participation, fertility and public policy in Sweden. European Journal of Population, 8, 199-215.

Tamis-LeMonda, C. S., Baumwell, L., \& Cabrera, N. J. (2013). Fathers' role in children's language development. In N. J. Cabrera \& C. S. Tamis-LeMonda (Eds.), Handbook of father involvement: Multidisciplinary perspectives (pp. 135-150). New York, NY: Routledge.

Thévenon, O., Ali, N., Adema, W., \& Salvi del Pero, A. (2012). Effects of reducing gender gaps in education and labour force participation on economic growth in the OECD (138).

Updegraff, K. A., Mchale, S. M., \& Crouter, A. C. (1996). Gender roles in marriage: What do they mean for girls' and boys' school achievement? Journal of Youth and Adolescence, 25(1), 73-88.

Wall, K., \& Leitão, M. (2018). Portugal country note. In S. Blum, A. Koslowski, A. Macht, \& P. Moss (Eds.), International review of leave policies and research 2018 (pp. 332-344).

Wilson, K. R., \& Prior, M. R. (2010). Father involvement: The importance of paternal Solo Care. Early Child Development and Care, 180(10), 1391-1405.

Yeung, W. J., Sandberg, J. F., Davis-Kean, P. E., \& Hofferth, S. L. (2001). Children's time with fathers in intact families. Journal of Marriage and Family, 63(1), 136154. 
Open Access This chapter is licensed under the terms of the Creative Commons Attribution 4.0 International License (http://creativecommons.org/licenses/by/4.0/), which permits use, sharing, adaptation, distribution and reproduction in any medium or format, as long as you give appropriate credit to the original author(s) and the source, provide a link to the Creative Commons licence and indicate if changes were made.

The images or other third party material in this chapter are included in the chapter's Creative Commons licence, unless indicated otherwise in a credit line to the material. If material is not included in the chapter's Creative Commons licence and your intended use is not permitted by statutory regulation or exceeds the permitted use, you will need to obtain permission directly from the copyright holder.

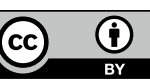

